\title{
PENGENDALIAN SUHU DAN KELEMBABAN PADA BUDIDAYA JAMUR TIRAM BERBASIS IOT
}

\section{IOT BASED CONTROLLING TEMPERATURE AND HUMIDITY ON OYSTER MUSHROOMS CULTIVATION}

\author{
Helmy Fitriawan $^{1 凶}$, Kholid Ali Dwi Cahyo ${ }^{1}$, Sri Purwiyanti ${ }^{1}$, Syaiful Alam ${ }^{1}$ \\ ${ }^{1}$ Jurusan Teknik Elektro, Fakultas Teknik, Universitas Lampung \\ ${ }^{\square}$ Komunikasi Penulis, email: helmy.fitriawan@eng.unila.ac.id \\ DOI:http://dx.doi.org/10.23960/jtep-l.v9i1.28-37 \\ Naskah ini diterima pada 25 Februari 2020; revisi pada 19 Maret 2020; \\ disetujui untuk dipublikasikan pada 22 Maret 2020
}

\begin{abstract}
Oyster mushrooms (Pleurotus Ostreatus) is one type of edible mushrooms. Oyster mushroom cultivation is usually done at the mushroom house (kumbung) which is mostly made of bamboo. Oyster mushrooms can grow optimally by controlling the temperature and humidity in the kumbung. Kumbung environment conditioning is usually done manually by spraying water on the planting medium every 8 hours. But this is perceived as ineffective and requires high effort. For this reason, we need a technology that can monitor as well as control the environmental conditions inside the kumbung automatically and remotely. This paper describes the design of a system to monitor and control the temperature and humidity in the kumbung for oyster mushroom cultivation based on IoT (Internet of Things). This system is developed consisting of five parts, i.e sensor modules, microcontrollers, data logger, actuators, and monitoring and control interfaces. The main result of this study is a remote monitoring and control of environmental conditions for oyster mushroom cultivation. The data of monitoring, in the form of temperature and humidity, are saved to the data logger and can be downloaded in the format (.csv). The system works functionally in accordance with the expected specifications, both in terms of sensor readings and actuator controlling.
\end{abstract}

Keywords: actuator, humidity, Oyster mushroom, sensor, temperature

\begin{abstract}
ABSTRAK
Jamur tiram (Pleurotus ostreatus) merupakan salah satu jenis jamur yang dapat dimakan. Budidaya jamur tiram dilakukan di rumah jamur (kumbung) yang biasanya terbuat dari bambu. Jamur tiram dapat tumbuh secara optimal dengan mengendalikan suhu dan kelembaban di dalam kumbung. Pengkondisian lingkungan kumbung biasanya dilakukan secara manual dengan penyemprotan air pada media tanam setiap 8 jam. Tetapi hal ini dirasakan tidak efektif dan memerlukan upaya kejerihan yang tinggi. Untuk itu diperlukan suatu teknologi yang dapat memantau dan juga mengendalikan kondisi lingkungan di dalam kumbung secara otomatis dari jarak jauh. Penelitian ini melakukan rancang bangun sistem pemantauan dan pengendalian suhu dan kelembaban di dalam kumbung untuk budi daya jamur tiram berbasis IoT (Internet of Things). Sistem dikembangkan secara modular terdiri dari lima bagian, yaitu modul sensor, mikrokontroler, data logger, aktuator dan antar muka pemantauan dan pengendalian. Hasil utama dari penelitian ini adalah berupa alat pemantauan dan pengendalian kondisi lingkungan budidaya jamur tiram secara jarak jauh. Data pemantauan, berupa suhu dan kelembaban, disimpan ke data logger dan dapat diunduh dalam format (.csv). Sistem secara fungsional berkerja sesuai dengan spesifikasi yang diinginkan baik dari sisi pembacaan sensor dan pengendalian aktuator.
\end{abstract}

Kata Kunci: actuator, Jamur tiram, kelembaban, sensor, suhu

\section{PENDAHULUAN}

Indonesia dikenal sebagai negara agraris yang mengandalkan bidang pertanian sebagai sektor andalan didalam pertumbuhan ekonominya. Sekitar 33,6 juta atau 27,65\% penduduknya bekerja di bidang pertanian (BPS, 2017). Sebagian besar petani masih menggunakan 
metode tradisional dalam teknik pertaniannya yang berakibat pada masih rendahnya hasil panen pertanian atau perkebunannya. Untuk meningkatkan hasil panen, salah satunya dibutuhkan penerapan teknologi otomasi modern yang efektif dan efisien pada bidang ini.

Salah satu tanaman pangan yang dibudidayakan adalah jamur tiram (Pleurotus ostreatus). Seperti halnya jenis jamur lainnya seperti jamur kancing, jamur kuping dan jamur merang, jamur tiram tidak berbahaya dan dapat dikonsumsi serta mempunyai kandungan nutrisi yang tinggi (Chakravarty, 2011). Jamur tiram, sesuai dengan namanya, mempunyai bentuk yang menyerupai cangkang kerang atau tiram. Dikarenakan rasanya yang enak, jamur tiram dapat dijumpai dalam olahan makanan seperti keripik dan oseng-oseng (Parjimo, 2013). Budidaya jamur tiram sangat cocok dilakukan di daerah dataran tinggi dengan iklim yang sejuk. Jamur tiram ditemukan pertama kali di alam yaitu pada batang-batang kayu yang sudah lapuk. Untuk menjaga kondisi suhu dan kelembaban ada pada kondisi yang diinginkan serta menghindari dari gangguan hama, angin, hujan dan intensitas cahaya yang terlalu tinggi, jamur tiram dibudidayakan di dalam rumah jamur atau yang disebut kumbung. Kumbung jamur biasanya terbuat dari bahan bambu yang banyak ditemukan di Indonesia. Budidaya jamur tiram di dalam kumbung biasanya dilakukan secara konvensional, yang mana pengkondisian suhu dan kelembaban dilakukan dengan cara penyemprotan air setiap pada pagi dan sore hari dengan hand sprayer (Suharjo, 2015). Perlakukan ini dapat menimbulkan permasalahan yaitu, tingkat suhu dan kelembaban yang dihasilkan hanya berdasarkan perkiraan saja. Hal tersebut juga membutuhkan upaya dengan kejerihan yang tinggi. Sehingga hasilnya dirasakan tidak efektif dan maksimal. Pengendalian suhu dan kelembaban di dalam kumbung harus dilakukan untuk menjaga pertumbuhan jamur tiram dengan baik dan optimal. Jamur tiram dapat tumbuh secara optimal dalam dua fase pertumbuhan yaitu, fase inkubasi yang memerlukan suhu $16-20^{\circ} \mathrm{C}$ dengan kelembaban $70-90 \%$ serta fase pembentukan tubuh buah yang memerlukan suhu $26-29^{\circ} \mathrm{C}$ dengan kelembaban 70-90\%. Dengan perkembangan teknologi elektronika, otomasi dan komunikasi, pemantauan dan pengendalian kondisi lingkungan di dalam kumbung dapat dilakukan secara otomatis dan secara jarak jauh.

Pada beberapa tahun terakhir, terdapat beberapa penelitian yang telah dilakukan untuk mengembangkan sistem pemantauan dan pengendalian kondisi lingkungan kumbung jamur secara otomatis. Pengendalian suhu pada kumbung jamur telah dilakukan dengan menggunakan metode logika fuzzy (Higuitta \& Cordova, 2013). Pada penelitian tersebut, digunakan model matematis untuk membuat pengendalian suhu terhadap kelembaban. Sementara pengendalian suhu pada kumbung jamur kuping dan tiram juga telah dilakukan oleh (Yamin, 2010). Pada penelitian ini dibandingkan hasil pemanenan jamur dengan mengendalikan kumbung jamur pada 3 (tiga) nilai suhu, yatu $17^{\circ} \mathrm{C}, 19^{\circ} \mathrm{C}$ dan $21^{\circ} \mathrm{C}$.

Sistem pengendalian suhu dan kelembaban untuk budidaya jamur kuping dikembangkan menggunakan mikrokontroler ATmega 16 (Gunawan, dkk., 2013). Pengendalian suhu dan kelembaban secara otomatis pada kumbung jamur tiram dilakukan disini (Sihombing, dkk., 2018). Pengendalian tersebut dapat dilakukan melalui smartphone Android melalui komunikasi Bluetooth. Sementara itu mikrokontroler berbasis IoT yaitu ESP8266 digunakan untuk mengendalikan suhu dan kelembaban kumbung jamur tiram secara realtime (Arafat, dkk., 2019). Pada sistem ini, parameter suhu dan kelembaban dapat dipantau dan dikendalikan melalui telepon pintar (smartphone) berbasis Android. Sementara penelitian oleh (Waluyo, dkk., 2018) menyimpulkan bahwa suhu dan kelembaban dalam kumbung jamur tiram dapat dikendalikan berdasarkan perubahan nilai suhu dan kelembaban dalam kumbung jamur.

Pada penelitian sebelumnya sudah berhasil dikembangkan pengendalian Greenhouse pada tanaman paprika (Fitriawan, dkk., 2018). Sistem tersebut dikembangkan secara modular menggunakan sensor suhu dan kelembaban, mikrokontroler Arduino, data logger, aktuator dan antar muka pemantauan dan pengendalian. Dengan menggunakan cara yang hampir sama pada penelitian ini dilakukan rancang bangun dan implementasi sistem pemantauan dan 
pengendalian suhu dan kelembaban pada budi daya jamur tiram. Antar muka pemantauan dan pengendalian dikembangkan berbasis web melalui aplikasi Ubidots (Ubidots IoT Platform), sehingga dapat dilakukan menggunakan telepon pintar melalui jaringan Internet. Sistem yang dirancang dapat mengendalikan suhu dan kelembaban di dalam kumbung secara otomatis atau secara manual mealui aplikasi sehingga jamur tiram dapat tumbuh dengan baik. Komponen sensor dan aktuator yang digunakan pada sistem ini diuji untuk melihat apakah dapat bekerja dengan baik dan sesuai dengan spesifikasinya. Kemudian juga dilakukan perbandingan data yang tersimpan pada data loger dan data yang tampil pada halaman web Ubidots.

\section{BAHAN DAN METODA}

\subsection{Perancangan Sistem}

Sistem yang dikembangkan terdiri dari beberapa bagian, yaitu bagian pembacaan suhu dan kelembaban, bagian pengolahan dan penyimpanan data, bagian komunikasi data, serta bagian aktuator. Rancang bangun sistem yang dikembangkan untuk pemantauan dan pengendalian kondisi lingkungan pada budidaya jamur tiram diperlihatkan pada Gambar 1.

Sensor DHT22 digunakan sebagai alat pembacaan suhu dan kelembaban lingkungan di sekitar media tanam. Sensor ini menggunakan sensor kelembaban kapasitif dan thermistor untuk medeteksi perubahan suhu udara disekitarnya. Sensor DHT22 banyak digunakan karena mempunyai kemampuan pembacaan suhu dan kelembaban yang cukup cepat dan akurat, serta jarak pembacaan cukup luas mencapai radius $20 \mathrm{~m}$. Sensor ini bekerja pada jangkauan kelembaban 0-100\% serta suhu pada $40-80^{\circ} \mathrm{C}$ dan mempunyai resolusi kelembaban $0,1 \%$ dan suhu $0,1^{\circ} \mathrm{C}$. Akurasi sensor ini adalah $\pm 2 \%$ untuk pembacaan kelembaban dan $0,5^{\circ} \mathrm{C}$ untuk pembacaan suhu (DHT22 Datasheet).

Sebagai bagian pengolah, komunikasi data dan penyimpan data digunakan Arduino Mega, ethernet shield dan mini data logger. Arduino merupakan platform perangkat keras bersifat terbuka (open source) untuk mikrokontroler papan tunggal (single-board) dengan dukungan input/ouput dan bahasa pemrograman standar. Arduino Mega 2560 yang digunakan pada sistem ini adalah papan mikrokontroler berbasis chip ATMega 2560. Arduino Mega mempunyai 54 pin input/output, 11 diantaranya dapat digunakan sebagai output PWM. Arduino Mega juga mempunyai 16 pin sebagai input analog. Arduino ini bekerja pada tegangan $5 \mathrm{~V}$ dan dilengkapi dengan osilator kristal $16 \mathrm{MHz}$, koneksi USB, koneksi untuk daya dan tombol reset (Arduino MEGA 2560 Datasheet). Sementara Ethernet shield W5100 digunakan sebagai pengkoneksi Arduino dengan jaringan Internet melalui kabel, dengan menyediakan IP untuk protokol TCP dan UDP. Untuk menggunakannya dibutuhkan pustaka (library) Ethernet dan SPI. Modul ini juga mempunyai sebuah onboard slot micro-SD, yang dapat digunakan untuk menyimpan data hasil pemmbacaan sensor (Arduino Ethernet Shield Datasheet).

Aktuator digunakan sebagai alat untuk mengendalikan kondisi lingkungan di dalam kumbung. Relay, lampu pijar dan pompa air DC sebagai aktuator pada sistem yang dikembangkan. Relay merupakan saklar yang beroperasi secara elektrikal dan mempuyai dua

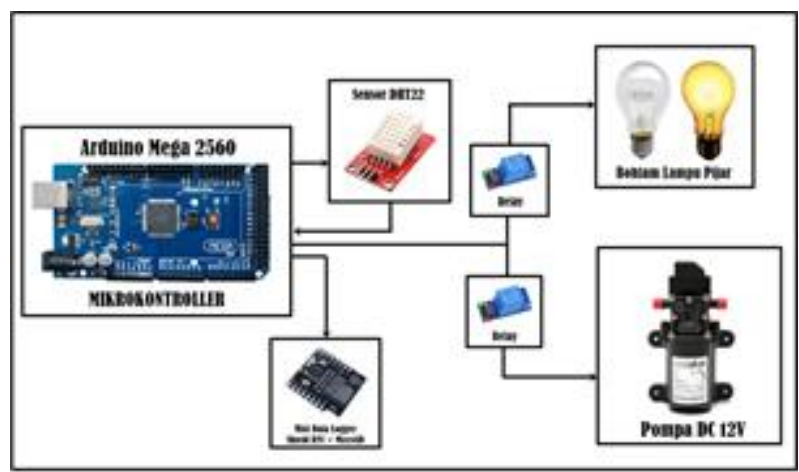

Gambar 1. Arsitektur Sistem Pengendalian Suhu dan Kelembaban pada Kumbung Jamur 
bagian utama yakni elektromagnetik (coil) dan mekanikal (kontak switch). Relay bekerja dengan menutup dan membuka rangkaian dengan tenaga listrik melalui coil yang terdapat didalamnya. Sementara lampu pijar digunakan untuk menghasilkan panas di dalam ruangan kumbung. Lampu pijar adalah sumber cahaya buatan yang dihasilkan melalui penyaluran arus listrik ke filamen yang kemudian memanas dan menghasilkan cahaya. Pada sistem ini, pompa air DC digunakan untuk mengalirkan dari tempat penampungan air dan mendorong air menuju nozzle. Nozzle inilah yang akan menyemprotkan air ke sekitar ruang media tanam untuk menurunkan suhu ruangan. Pompa air yang digunakan bekerja dengan tegangan listrik $12 \mathrm{~V}$.

Setelah semua perangkat keras telah selesai dirakit, tahap berikutnya dilakukan pemrograman. Pemrograman pada mikrokontroler Atmega dilakukan menggunakan perangkat lunak Arduino IDE (Integrated Developmen Environment) 1.8.5 (Arduino IDE). Mikrokontroler diprogram agar berperilaku sesuai dengan yang diinginkan, mulai dari pengambilan data hasil pembacaan sensor, penyimpanan data pada data loger, mengambil keputusan mengaktifkan atau menonaktifkan aktuator terkait hasil pembacaan suhu dan kelembaban.

\subsection{Implementasi Sistem}

Setelah proses perancangan dan perakitan sistem selesai dilakukan, tahap berikutnya adalah pemasangan sistem pada kumbung atau rumah jamur. Gambar 2. mengilustrasikan tata letak penempatan sistem pemantauan dan pengendalian, termasuk sensor, aktuator dan sistem komunikasi yang digunakan.

Pada gambar tersebut tersebut terlihat, sensor DHT22 (1) ditempatkan dekat pada media tanam jamur untuk mengukur suhu dan kelembaban (2). Sensor dipasang di beberapa titik pada media tanam untuk membaca suhu dan kelembaban ruangan media tanam. Hasil pembacaan dikirimkan pada mikrokontroler yang ada di kotak pengendalian (5), bersama dengan data logger, relay dan pompa air. Apabila dari hasil pembacaan suhu dan kelembaban menunjukkan kondisi ruang terlalu panas (suhu diatas setting point) dan atau terlalu kering (kelembaban dibawah setting point), maka pompa air akan menyala untuk kemudian dilakukan penyemprotan air dalam bentuk kabut pada media tanam melalui nozzle (4). Jika kondisi suhu dan kelembaban sudah dalam kondisi ideal yang diinginkan, pompa akan diperintahkan untuk mati. Sementara apabila dari hasil pembacaan suhu dan kelembaban menunjukkan sebaliknya, yaitu suhu terlalu dingin (dibawah setting point) dan atau terlalu lembab (kelembaban diatas setting point) maka lampu pijar (3) akan dihidupkan untuk menaikkan suhu ruang media tanam. Kemudian laptop (6), selain digunakan untuk melakukan pemrograman terhadap mikrokontroler yang digunakan, juga sebagai pengirim data hasil pengukuran ke Ubidots (Ubidots IoT Platform). Bersamaan dengan pembacaan suhu dan kelembaban, data yang didapat akan disimpan ke data logger, dan data yang didapat pun dapat langsung dipantau secara real time menggunakan smartphone (8) melalui jaringan Internet (7). Sistem ini memiliki kemampuan sebagai alat pemantau dan pengondisi suhu serta kelembaban di kumbung jamur tiram yang bisa dikendalikan dari jarak jauh secara melalui web Ubidots serta dapat menampilkan informasi tentang kondisi suhu serta kelembaban pada kumbung jamur tiram secara real-time dan tampilannya dalam bentuk grafik. Data informasi suhu dan kelembaban lingkungan setiap saat dapat diunduh dalam bentuk tabel dalam format (.csv).

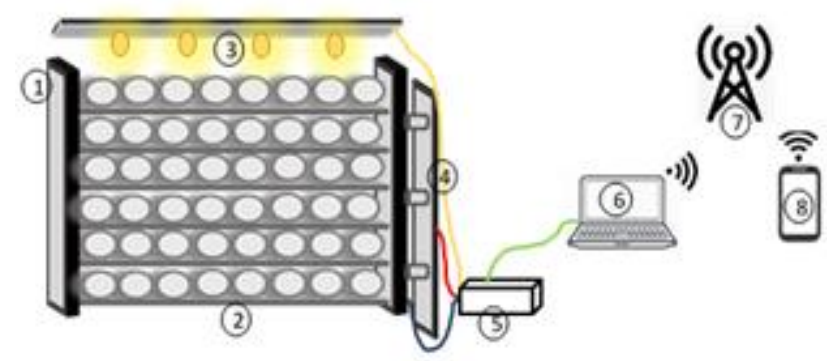

Gambar 2. Ilustrasi Pemasangan Sistem Pemantauan pada Kumbung Jamur Tiram 


\section{HASIL DAN PEMBAHASAN}

\subsection{Pengendalian Sistem}

Hasil utama dari penelitian ini adalah berupa alat pemantauan dan pengendalian kondisi lingkungan budidaya jamur tiram secara jarak jauh. Alat dapat melakukan pengukuran. Hasil pemantauan dan pengendalian, berupa suhu dan kelembaban disimpan ke data logger, data tersebut dapat diunduh dengan format (.csv) dan dapat dibuka menggunakan perangkat lunak pengolah tabel. Data tersebut juga dapat dilihat secara real time dengan cara mengakses halaman Ubidots, dan login menggunakan akun yang sebelumnya telah dibuat. Halaman web pemantauan dan pengendalian suhu dan kelembaban kumbung jamur dikembangkan menggunakan aplikasi Ubidots (Gambar 3). Pada halaman tersebut terdapat 7 (tujuh) subbagian antarmuka pemanatauan dan pengendalian, yaitu: (1) tampilan grafik hasil pembacaan suhu dan kelembaban dalam rentang waktu 30 menit terakhir, (2) dan (3) merupakan tampilan hasil pembacaan masing-masing suhu dan kelembaban pada waktu terkini (update), (4) merupakan menu tombol untuk mematikan atau menghidupkan lampu secara manual dari jarak jauh melalui aplikasi, (5) adalah menu tombol untuk menghidupkan atau mematikan pompa motor DC dari jarak jauh melalui aplikasi, sementara (6) dan (7) merupakan tampilan indikator yang menginformasikan status apakah lampu dan pompa motor DC dalam keadaan hidup atau mati.

Pengendalian suhu dan kelembaban dilakukan menggunakan mikrokontroler Arduino Mega 2560. Pada saat sensor DHT22 melakukan pembacaan kelembaban, hasil pembacaan tersebut dikirimkan ke mikrokontroler lalu data tersebut menjadi acuan untuk melakukan tindakan selanjutnya. Arduino mengirimkan sinyal ke relay untuk mengaktifkan atau menonaktifkan aktuator water pump $D C$ dan bohlam lampu pijar sesuai dengan set point yang sebelumnya telah ditentukan. Tabel 1 . berikut memperlihatkan batas minimum dan maksimum dari parameter suhu dan kelembaban yang dikehendaki dalam sistem.

\subsection{Pengujian Komponen Sistem}

Pengujian komponen dilakukan dengan cara membandingkan hasil ukur sensor suhu dan kelembaban dengan alat instrumen, kemudian juga dilakukan pengujian kinerja relay dan pompa.

\subsubsection{Pengujian Sensor Suhu dan Kelembaban}

Pengujian sensor dilakukan dengan membandingkan hasil pengukuran dari sensor yang digunakan dengan alat ukur yang sudah



Gambar 3. Halaman Utama Antarmuka Pemantauan, Pengendalian Suhu, dan Kelembaban Kumbung Jamur Tiram dari Ubidots 
Tabel 1. Batas Nilai Pengendalian Suhu dan Kelembaban

\begin{tabular}{ccc}
\hline Parameter & Batas Minimum & Batas Maksimum \\
\hline Suhu & $26^{\circ} \mathrm{C}$ & $29^{\circ} \mathrm{C}$ \\
Kelembaban & $70 \%$ & $90 \%$ \\
\hline
\end{tabular}

Tabel 2. Kalibrasi Pembacaan Suhu dan Kelembaban

\begin{tabular}{cccc|cccc}
\hline \multicolumn{2}{c}{ Sensor 1 } & \multicolumn{2}{c|}{ Instrumen } & \multicolumn{2}{c}{ Sensor 2 } & \multicolumn{2}{c}{ Instrumen } \\
\hline $\begin{array}{c}\text { Suhu } \\
\left.\mathbf{(}{ }^{\circ} \mathbf{C}\right)\end{array}$ & $\begin{array}{c}\text { Kelembaban } \\
\mathbf{( \% )}\end{array}$ & $\begin{array}{c}\text { Suhu } \\
\left.\mathbf{(}{ }^{\circ} \mathbf{C}\right)\end{array}$ & $\begin{array}{c}\text { Kelembaban } \\
\mathbf{( \% )}\end{array}$ & $\begin{array}{c}\text { Suhu } \\
\left.\mathbf{(}{ }^{\circ} \mathbf{C}\right)\end{array}$ & $\begin{array}{c}\text { Kelembaban } \\
\text { S\%) }\end{array}$ & $\begin{array}{c}\text { Suhu } \\
\left.\mathbf{(}{ }^{\circ} \mathbf{C}\right)\end{array}$ & $\begin{array}{c}\text { Kelembaban } \\
(\%)\end{array}$ \\
\hline 31,10 & 73,8 & 31,40 & 74 & 30,70 & 75,1 & 30,60 & 74 \\
31,10 & 73,8 & 31,40 & 74 & 30,70 & 75,1 & 30,60 & 74 \\
31,10 & 73,6 & 31,40 & 73 & 30,60 & 74,9 & 30,60 & 74 \\
31,10 & 73,6 & 31,40 & 73 & 30,60 & 74,9 & 30,60 & 74 \\
31,10 & 73,3 & 31,27 & 73 & 30,60 & 74,7 & 30,60 & 74 \\
31,10 & 73,3 & 31,20 & 73 & 30,60 & 74,7 & 30,60 & 74 \\
31,10 & 72,9 & 31,20 & 73 & 30,70 & 74,6 & 30,70 & 74 \\
31,10 & 72,9 & 31,20 & 73 & 30,70 & 74,6 & 30,70 & 74 \\
31,10 & 72,8 & 31,10 & 73 & 30,70 & 74,4 & 30,90 & 74 \\
31,10 & 72,8 & 31,10 & 73 & 30,70 & 74,4 & 30,90 & 74 \\
31,10 & 72,8 & 31,10 & 73 & 30,60 & 74,4 & 30,90 & 74 \\
31,10 & 72,8 & 31,05 & 73 & 30,60 & 74,4 & 30,90 & 74 \\
31,10 & 72,8 & 31,05 & 72 & 30,70 & 74,5 & 30,90 & 74 \\
31,10 & 72,8 & 31,05 & 72 & 30,70 & 74,5 & 31,30 & 74 \\
31,10 & 72,8 & 31,05 & 72 & 30,70 & 74,7 & 31,30 & 74 \\
\hline
\end{tabular}

diketahui akurasinya. Pembacaan suhu dan kelembaban dengan sensor DHT22 yang digunakan pada rancangan sistem dibandingkan dengan instrumen Thermometer + Hygrometer Digital (Tabel 2). Karena terdapat dua sensor yang digunakan pada sistem maka dilakukan perbandingan masing-masing sensor tersebut dengan instrumen alat ukur. Pengujian pada masing-masing sensor dilakukan sebanyak 15 kali pembacaan dengan jeda 1 detik. Dari hasil perbandingan, didapatkan sensor 1 mempunyai masing-masing rata-rata galat (error) pembacaan suhu sebesar $0,09^{\circ} \mathrm{C}$ dan kelembaban sebesar 0,5\%. Sementara rata-rata galat pada sensor 2 sebesar $0,14^{\circ} \mathrm{C}$ untuk suhu dan $0,1 \%$ untuk kelembaban. Hasil perbandingan memperlihatkan nilai galat masih berada pada kawasan kerja sensor DHT22, sehingga disimpulkan bahwa kedua sensor dapat bekerja dengan baik dan dapat digunakan pada sistem ini.

\subsubsection{Pengujian Relay}

Pengujian relay dilakukan dengan cara mengaktifkan relay, saat relay aktif terdengar bunyi klik dan LED pada board akan menyala, yang menandakan bahwa titik kontak relay telah berpindah dari kondisi tertutup ke kondisi terbuka. Gambar 4.a). memperlihatkan relay ada dalam kondisi terbuka (normally open, NO) dan Gambar 4.b). memperlihatkan relay ada dalam kondisi tertutup (normally close, NC). Dari pegujian, tersebut didapatkan relay yang digunakan dapat bekerja dengan baik.

\subsubsection{Pengujian Pompa Motor}

Pompa motor DC $12 \mathrm{~V}$ digunakan sebagai aktuator untuk menyemprotkan air dengan menggunakan selang 3/8 inch. Sementara pada ujung selang digunakan nozzle yang dapat menghasilkan efek air kabut dari air yang dikeluarkan. Pengujian pompa DC dilakukan dengan cara menghidupkan pompa secara manual menggunakan adaptor. Hasil pengujian memperlihatkan motor DC dapat bekerja baik dan menghasilkan kabut dengan baik melalui nozzle. Pengujian pompa dilakukan dengan menggunakan relay yang terhubung dengan sumber tegangan. Pengujian tersebut dilakukan karena pompa akan diatur menggunakan 


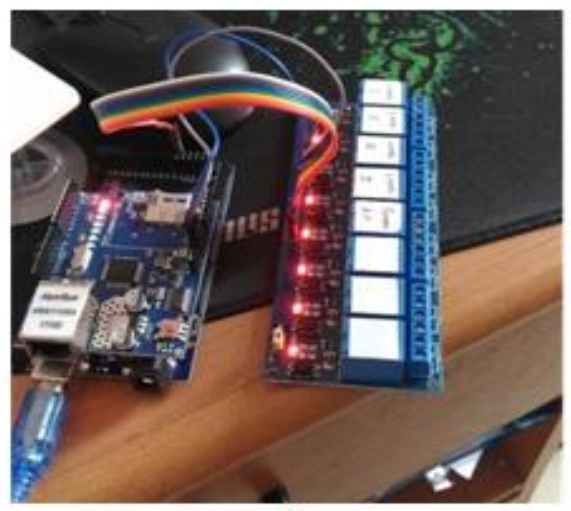

(a)

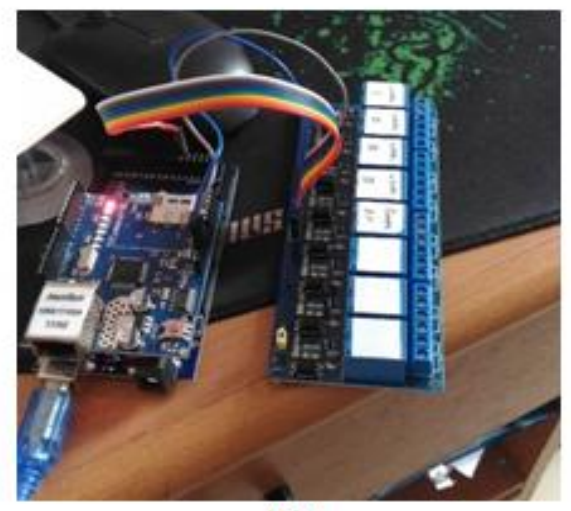

(b)

Gambar 4. (a) Rangkaian Relay dalam Keadaan Terbuka (Normally Open) dan (b) Rangkaian Relay dalam Keadaan Tertutup (Normally Close)

Tabel 3. Pengujian Pompa Motor DC Menggunakan Relay

\begin{tabular}{ccc}
\hline No. & Relay & Motor DC \\
\hline 1 & ON & ON \\
2 & OFF & OFF \\
3 & ON & ON \\
4 & OFF & OFF \\
5 & ON & ON \\
\hline
\end{tabular}

mikrokontroler melalui relay, karena relay berfungsi sebagai penghubung dan pemutus arus listrik. Hasil pengujian pompa menggunakan relay dapat dilihat pada Tabel 3.

\subsection{Pengujian Sistem}

Pengujian sistem dilakukan dengan cara menguji tanggapan aktuator terhadap perubahan nilai pembacaan sensor suhu dan kelembaban, pengujian waktu tunda tanggapan aktuator ketika diberikan perintah secara manual melalui antarmuka aplikasi, serta pengujian perbandingan data yang tersimpan pada data logger dan data yang terlihat pada web aplikasi ubidots.

\subsubsection{Tanggapan Aktuator Terhadap Pembacaan Sensor}

Pengujian tanggapan aktuator terhadap pembacaan sensor dilakukan dengan cara melihat perubahan perilaku aktuator terhadap berbagai nilai pembacaan sensor berdasarkan batas nilai suhu dan kelembaban seperti pada Tabel 1. Pengujian dilakukan selama 10 kali dengan jeda waktu 30 detik untuk setiap pengujian. Tabel 4 memperlihatkan hasil pengujian tanggapan aktuator (motor DC dan lampu pijar) terhadap pembacaan sensor suhu dan kelembaban. Pada pengujian ke-1 sampai dengan ke-3 memperlihatkan pompa dalam keadaan OFF atau mati disebabkan suhu kumbung masih dalam rentang suhu yang diharapkan $\left(26^{\circ} \mathrm{C}-29^{\circ} \mathrm{C}\right)$. Sementara itu lampu dalam keadaan $\mathrm{ON}$ atau hidup untuk menurunkan kelembaban yang masih diatas 90\%, kemduian setelah kelembaban turun dibawah 90\% lampu dalam keadaan mati (Pengujian ke-4). Pada pengujian berikutnya yaitu pengujian ke-5 sampai dengan ke-7, pompa air mulai hidup untuk mengalirkan air karena suhu kumbung sudah mulai panas diatas $90^{\circ} \mathrm{C}$ tetapi lampu tetap dalam keadaan mati karena kumbung masih cukup lembab dibawah $90 \%$. Ketika kelembaban mulai naik diatas $90 \%$ seperti pada pengujian ke-8, maka lampu akan mulai hidup. Setelah kelembaban turun kembali dibawah $90 \%$ seperti pada pengujian ke-9 dan 10, maka lampu akan kembali dalam keadaan mati. Tabel 4 tersebut menunjukkan bahwa apabila suhu melebihi batas dari yang ditetapkan yaitu $29^{\circ} \mathrm{C}$ maka motor DC akan ON atau hidup sehingga pada kondisi tersebut air akan dialirkan untuk menghasilkan proses pengkabutan yang akan menurunkan suhu kumbung. Sementara apabila didapatkan kelembaban yang lebih tinggi 
dari 90\%, maka lampu akan ON atau hidup. Pengujian ini memberikan kesimpulan bahwa aktuator $100 \%$ berhasil memberikan tanggapan terhadap kondisi kumbung melalui pembacaan sensor suhu dan kelembaban.

\subsubsection{Waktu Tunda Tanggapan Aktuator Melalui Perintah Aplikasi}

Sistem yang dirancang ini dapat dikendalikan melalui perintah manual dari antarmuka aplikasi Ubidots (Gambar 3). Pada pengujian ini, dilakukan pengukuran waktu yang dibutuhkan aktuator untuk menanggapi perintah yang diberikan dari aplikasi Ubidots tersebut. Tabel 5 memperlihatkan hasil pengujian tanggapan aktuator yang dikendalikan melalui aplikasi dan waktu tunda yang dibutuhkan ketika aktuator mulai menanggapi perintah tersebut. Hasil pengujian memperlihatkan aktuator 3 kali tidak dapat memberikan tanggapan dari perintah yang diberikan melalui aplikasi secara akurat, sehingga terdapat kesalahan tanggapan aktuator sebesar $(3 / 24 \times 100 \%)=12,5 \%$. Sementara ratarata waktu tunda tanggapan sebesar 29,45 detik untuk pompa DC dan 29,4 detik untuk lampu pijar. Nilai waktu tunda sebesar tersebut untuk aplikasi pemantauan dan pengendalian kumbung masih dapat diterima.

\subsubsection{Perbandingan Data pada Data Logger dan Web Ubidots}

Pengujian ini dilakukan dengan mengambil sampel data dengan mengunduh data dari Web Ubidots kemudian membandingkannya dengan data tersimpan di data logger. Pengambilan data dilakukan selama rentang waktu 1 jam dengan

Tabel 4. Pengujian Tanggapan Aktuator Terhadap Pembacaan Sensor

\begin{tabular}{ccccc}
\hline \multirow{2}{*}{ No. } & \multicolumn{2}{c}{ Pembacaan Sensor } & \multicolumn{2}{c}{ Instrumen } \\
\cline { 2 - 5 } & Suhu $\left({ }^{\circ} \mathbf{C}\right)$ & Kelembaban (\%) & Motor DC/ Pompa & Lampu Pijar \\
\hline 1 & 28.75 & 90.85 & OFF & ON \\
2 & 28.90 & 91.75 & OFF & ON \\
3 & 28.85 & 90.45 & OFF & ON \\
4 & 28.95 & 89.90 & OFF & OFF \\
5 & 29.05 & 90,00 & ON & OFF \\
6 & 29.10 & 89.85 & ON & OFF \\
7 & 29.20 & 89.90 & ON & OFF \\
8 & 29.45 & 90.20 & ON & ON \\
9 & 29.50 & 88.85 & ON & OFF \\
10 & 29.95 & 88.20 & ON & OFF \\
\hline
\end{tabular}

Tabel 5. Pengujian Tanggapan Aktuator Terhadap Pembacaan Sensor

\begin{tabular}{ccccccc}
\hline \multirow{2}{*}{ No. } & Perintah Melalui Aplikasi & \multicolumn{2}{c}{$\begin{array}{c}\text { Tangapan Aktuator } \\
\text { Aktual }\end{array}$} & \multicolumn{2}{c}{$\begin{array}{c}\text { Waktu Tunda } \\
\text { (Detik) }\end{array}$} \\
\cline { 2 - 7 } & Pompa & Lampu Pijar & Pompa & Lampu Pijar & Pompa & Lampu Pijar \\
\hline 1 & ON & OFF & ON & OFF & 30 & 26 \\
2 & ON & OFF & OFF & OFF & - & 32 \\
3 & ON & OFF & ON & OFF & 30 & 30 \\
4 & OFF & ON & OFF & ON & 30 & 29 \\
5 & OFF & ON & OFF & ON & 30 & 28 \\
6 & OFF & ON & OFF & ON & 27 & - \\
7 & ON & ON & ON & ON & 29 & - \\
8 & ON & ON & ON & ON & 30 & 30 \\
9 & ON & ON & ON & ON & 31 & 29 \\
10 & OFF & OFF & OFF & OFF & 30 & 30 \\
11 & OFF & OFF & OFF & OFF & 28 & 30 \\
12 & OFF & OFF & OFF & OFF & 29 & 30 \\
\hline \multicolumn{7}{c}{ Rata-Rata Waktu Tanggapan } \\
\hline
\end{tabular}


Tabel 6. Pengujian Perbandingan Data pada Data Logger dan Ubidots

\begin{tabular}{cccccc}
\hline \multirow{2}{*}{ No. } & \multirow{2}{*}{ Waktu } & \multicolumn{2}{c}{ Data offline } & \multicolumn{2}{c}{ Data online } \\
\cline { 3 - 6 } & & Suhu $\left({ }^{\circ} \mathbf{C}\right)$ & Kelembaban (\%) & Suhu $\left({ }^{\circ} \mathbf{C}\right)$ & Kelembaban (\%) \\
\hline 1 & 08.01 & 29,45 & 85,25 & 29,45 & 85,25 \\
2 & 08.05 & 29,40 & 85,80 & 29,40 & 85,80 \\
3 & 08.10 & 29,55 & 85,75 & 29,55 & 85,75 \\
4 & 08.15 & 29,70 & 85,30 & 29,70 & 85,30 \\
5 & 08.20 & 29,65 & 85,25 & 29,65 & 85,25 \\
6 & 08.25 & 29,60 & 85,25 & 29,60 & 85,25 \\
7 & 08.30 & 29,65 & 85,15 & 29,65 & 85,15 \\
8 & 08.35 & 29,75 & 84,85 & 29,75 & 84,85 \\
9 & 08.40 & 29,75 & 84,65 & 29,75 & 84,65 \\
10 & 08.45 & 29,75 & 84,45 & 29,75 & 84,45 \\
11 & 08.50 & 29,80 & 84,35 & 29,80 & 84,35 \\
12 & 08.55 & 29,95 & 83,95 & 29,95 & 83,95 \\
13 & 09.00 & 29,85 & 84,15 & 29,85 & 84,15 \\
\hline \multicolumn{5}{c}{ Keberhasilan Pengiriman Data = 100\% } \\
\hline
\end{tabular}

jeda waktu 5 menit setiap pengambilan data seperti terlihat pada Tabel 6. Dari hasil perbandingan tersebut, terlihat bahwa kedua data tersebut mempunyai nilai yang sama sehingga berarti penyimpanan pada data logger dan data yang tersimpan pada aplikasi berjalan dengan baik dan data dapat diunduh dan disimpan dalam format berkas .csv. Hasil pengujian ini menunjukkan bahwa sistem berhasil 100\% dalam mengirimkan data hasil pembacaan suhu dan kelembaban baik ke aplikasi Ubidots (online) dan ke data logger (offline).

\section{KESIMPULAN}

Dari hasil penelitian dapat disimpulkan secara fungsionalitas sistem dapat bekerja secara baik terbukti bahwa suhu dan kelembaban dalam kumbung dapat dikendalikan secara otomatis mengikuti rentang nilai suhu dan kelembaban yang diinginkan. Sensor DHT22 dapat melakukan pembacaan suhu dan kelembaban secara akurat dimana nilai galat masih berada pada kawasan kerja sensor. Dari hasil perbandingan dengan instrumen pengukuruan suhu dan kelembaban, didapatkan sensor 1 dan sensor 2 mempunyai rata-rata galat (error) pembacaan suhu masing-masing sebesar $0,09^{\circ} \mathrm{C}$ dan $0,14^{\circ} \mathrm{C}$ sementara rata-rata galat pembacaan kelembaban masing-masing sebesar $0,5 \%$ dan $0,1 \%$. Sistem juga dapat dikendalikan melalui antarmuka aplikasi yang dapat diakses melalui
Internet. Aktuator sistem dapat menanggapi perintah yang diinputkan melalui aplikasi. Ratarata waktu tunda tanggapan aktuator adalah sebesar 29,45 detik untuk pompa DC dan 29,4 detik untuk lampu pijar. Hasil pemantauan berupa pembacaan suhu dan kelembaban juga dapat disimpan dalam data logger atau disimpan di web aplikasi. Hasil pengujian menunjukkan bahwa sistem berhasil $100 \%$ dalam mengirimkan data hasil pembacaan suhu dan kelembaban baik ke aplikasi Ubidots (online) dan ke data logger (offline).

\section{DAFTAR PUSTAKA}

Arafat, Puspitasari, D.I., Wagino, 2019. Sistem Pengendalian Suhu dan Kelembaban Kumbung Jamur Tiram secara Realtime Menggunakan ESP8266. Jurnal Fisika FLUX 1 (1):6-12.

Arduino Ethernet Shield Datasheet. Diakses dari https://www.arduino.cc/en/Main/ ArduinoEthernetShieldV1

Arduino IDE. Diakses dari https:// www.arduino.cc/en/main/software

Arduino MEGA 2560 Datasheet. Diakses dari https://store.arduino.cc/usa/mega2560-r3. 
BPS., 2017. Survei Angkatan Kerja Nasional (Sakernas). Diakses dari https:// www.bps.go.id.

Chakravarty, B., 2011. Trends in Mushroom Cultivation and Breeding. Australian Journal of Agricultural Engineering 2 (44):102-109.

DHT22 Datasheet. Digital-output relative humidity \& temperature sensor/ module DHT22. Aosong Electronics Co. Ltd.

Fitriawan., H., Dwipakresna I.B.M., Sulistyanti S.R., Trisanto, A., 2018. Pemantauan dan Pengendalian Kondisi Lingkungan Greenhouse Tanaman Paprika dengan Teknologi ZigBee. Prosiding Seminar Nasional Teknik Elektro, Fortei 2018. hal. 185-188.

Gunawan, F.A., Iftadi, I., Jauhari, W.A., 2013. Perancangan Sistem Pengendali Suhu dan Kelembaban untuk Budidaya Jamur Kuping. Performa: Media Ilmiah Teknik Industri 12 (1):33-38.

Higuitta, M.E., Cordova H., 2013. Perancangan Sistem Pengendalian Suhu dan Kumbung Jamur dengan Logika Fuzzy. Jurnal Teknik Pomits 2 (2):183-188.
Parjimo, A., 2013. Budidaya Jamur (Jamur Kuping, Jamur Tiram, Jamur Merang). Jakarta: AgroMedia Pustaka.

Sihombing, P., Astuti, T.P., Herriyance, Sitompul D., 2018. Microcontroller based automatic temperature control for oyster mushrooms plants. IOP Conf. Series: Journal of Physics: Conf. Series 978.

Suharjo, E., 2015. Budidaya Jamur Tiram Media Kardus. Jakarta: AgroMedia Pustaka.

Ubidots IoT Platform. Diakses dari https:// ubidots.com/

Waluyo, S., Wahyono, R.E., Lanya, B., Telaumbanua, M., 2018. Pengendalian Temperatur dan Kelembaban dalam Kumbung Jamur Tiram (Pleurotus $s p$ ) Secara Otomatis Berbasis Mikrokontroler. Agritech 38 (3):282288.

Yamin, M., 2010. Budidaya Jamur Kuping dan Tiram dengan Teknologi Pengendalian Suhu. Jurnal Pangan 19 (2):189-195. 